\title{
The United Nations Convention on the Rights of the Child: a milestone for a pedagogical reflection on the meanings of childhood and democracy
}

\author{
Chiara Carla Montà ${ }^{1}$ \\ ORCID: 0000-0002-1852-0093 \\ Lucia Carriera $^{1}$ \\ ORCID: 0000-0003-2503-8083 \\ Elisabetta Biffi ${ }^{1}, 2$ \\ ORCID: 0000-0002-1920-2185
}

\section{Abstract}

The present contribution offers a pedagogical reflection on the meanings of childhood and democracy through the ages, taking the United Nations Convention on the Rights of the Child as a culmination point, a turning point and a starting point for considering these concepts. Childhood is a socio-cultural construct originating from a twofold movement: the adult construction of childhood through education and politics and the way children in flesh and bone participate in the everyday life of their families and communities, contributing to defining what a child can do and be in a certain society. The first section of the paper explores the mentioned twofold movement from the Middle Ages to the twentieth century, preparing the foundations for the development of the United Nations Convention on the Rights of the Child (UNCRC) in 1989. The UNCRC led to a shift in the way childhood is conceived whose roots lie in recognizing what children in flesh and bone had "quietly" been doing and being for ages, so in this sense it is a culmination point. The paper then deepens the analysis of the UNCRC, specifically focusing on how the participation rights offer a particular perspective on democracy, understood as a way of life that needs to be learnt. The paper ends with a reflection on the future of democracy as can be seen in the UN 2030 Agenda for Sustainable Development which is based on the UNCRC itself.

\section{Keywords}

UNCRC - Childhood - Democracy - Participation.

1- University of Milano-Bicocca, Milano, Italy. Contact: c.monta@campus.unimib.it; I.carriera@campus.unimib.it; elisabetta.biffi@unimib.it.

2- The present contribution has been designed by the three authors. At the same time, paragraph 1 can be attributed to Lucia Carriera; paragraphs 2, 2.1 and 2.2 to Chiara Carla Montà and paragraph 3 to Elisabetta Biffi.

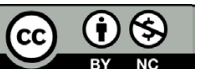




\section{Convenção das Nações Unidas sobre Direitos da Criança: marco para reflexão sobre infância e democracia}

\section{Resumo}

O presente artigo objetiva realizar uma reflexão pedagógica sobre os significados de infância e democracria ao longo dos tempos, considerando a Convenção das Nações Unidas sobre os Direitos da Criança (CNUDC) como um marco no pensamento destes conceitos, pensando-os, especificamente, como ponto culminante, ponto de virada e ponto de partida. A infância é uma construção sociocultural que se origina de um movimento duplo: a construção adulta da infância por meio de educação e politica e a maneira como as crianças de carne e osso participam do cotidiano de suas famílias e comunidades, contribuindo para definir o que uma criança pode fazer. A primeira seção do artigo explora o movimento duplo mencionado da Idade Média ao século XX, preparando as bases para $o$ desenvolvimento da Convenção das Nações Unidas sobre os Direitos da Criança em 1989, que liderou uma mudança no modo como a infância é concebida, uma mudança que tem suas raizes no reconhecimento do que as crianças de carne e osso estavam fazendo e sendo 'silenciosamente' por eras, por isso é um ponto culminante nesse sentido. $O$ artigo, então, aprofunda a análise da CNUDC, concentrando-se especificamente em como os direitos de participação oferecem uma perspectiva específica sobre democracia, compreendida como um modo de vida que precisa ser aprendido também pelas crianças. 0 artigo finaliza com uma reflexão sobre o futuro da democracia visto na Agenda 2030 da Organização das Nações Unidas para o Desenvolvimento Sustentável, a qual se baseia na própria CNUDC.

\section{Palavras-chave}

CNUDC - Infância - Democracia - Participação.

\section{Childhood and children through the ages: laying the foundations for UNCRC}

Childhood as a category does not exist in itself. It is the result of a socio-cultural construction by adults, who have developed le sentiment de l'enfance (ARIĖS, 1962) and by children themselves, in flesh and bone, that gives meaning to the category by participating in the social world (BECCHI, 1994). The following paragraphs, not intended to be exhaustive, will present some 'snapshots' taken from the history of childhood, starting off in the Middle Ages and reaching the $20^{\text {th }}$ century; they are the foundations on which the United Nations Convention on the rights of the Child (UNCRC) developed. The UNCRC in fact is underpinned by a certain idea of childhood, of education and, as will be argued, of democracy as well. 
The idea of children as something 'specific', with identifiable differences from adults, connected to specific needs to be translated into specific sorts of attention, is still part of a cultural construction adults have made along the centuries. For a long time, a child was easily considered a not-yet-adult to be transformed into an adult as soon as possible. Education, since the beginning of the human history, has always been identified as the medium through which children are turned into adults. In this sense, the form education took during the centuries reflected the idea of the adult the society wanted to shape.

In order to understand childhood, it is useful to mention the images of childhood that circulated in the past (ULIVIERI, 2001; SEVES0, 2001) and those, as will be discussed in this first section, drift primarily from the ecclesiastical world and from the literature on childhood often focused on children in working contexts. Images represented the main, if not the only, source of information and were used to teach the population.

During the Middle Ages children were institutionally educated by two main institutions, aside from the family: the church and the workplace.

For what concerns the Catholic church, visual culture was the main educational device at the time. Ecclesiastical iconography, including not only images but also stories around those images, conveyed values and behaviours to the young minds. The power of images is recognized by Philip Ariès, who studied iconography in order to get an understanding of what childhood meant in the past and how children were educated. On the contrary, Protestant countries tried to favour the literacy of the masses and of the new generations (GIALLONG0, 2001). Thinkers at that time such as Erasmus of Rotterdam (2000) welcomed images as a guide for behaviour (CAMBI, 2000). For example, when representing infants, Dominici depicts the image of the Virgin Mary with Jesus in her arms in a bucolic and reassuring landscape, inspired by holiness. Artists, in order to express the idea of purity and childlike innocence, used pale colours for the faces and candid colours for the clothing. The painting represents the 'ideal childhood' that is free from hostility, whim or rebellion at which to aspire to.

Visual education for young boys included dramatic images. Think for example of the Massacre of the Innocents used by ecclesiastical educators to instil horror in children towards violence, weapons, and the military art. Here the contrast between the ecclesiastical and the aristocratic model, anchored on military training, emerges. On the other hand, girls' education was founded on the 'good model of conduct' embodied in the images of the saints (Saint Agnes, Saint Cecilia etc.). Education in this period was not directed at childhood itself but at the women or men that children would become.

Unfortunately, there are just a few records showing the children's early year at that time. Demographers claim that infant mortality was about 30-50\%, and girls were more likely to die prematurely compared to boys (HANAWALT, 1995). This was due to the nature of the care boys enjoyed: it was qualitatively higher compared to the girls. It seems that males were of greater social worth (HANAWALT, 1995) because a daughter involved expenses (considering the dowry of marriage, for example), while a male child would instead bring wealth.

The urban European environment of the $17^{\text {th }}$ and $18^{\text {th }}$ centuries was characterized by very high rates of infant mortality due to terrible hygienic and food conditions children 
of time were subjected to. The care given to childhood was clearly inferior to today's (PANCERA, 2001). In the same period, artisan work was spreading in the households. In the narrow dwellings of the time (having just one room used as kitchen, laboratory and bedroom), everyday life had various problems. First of all, handling the offspring: the youngest children were usually sent to nurse, whereas children aged from three and eight were sent to work as apprentices (FLANDRIN, 1979). The first substantial difference between the socialization of children who worked and those who did not emerges here: children who did not work were often abandoned and left to themselves, it is assumed that the youngest were subject to the control of the eldest, such as older siblings. The transition into employment, however, did not happen in a sudden way. As soon as children were able to walk, around three years of age, they were asked to take part in simple activities, contributing to family life. To a certain extent the proposed activities took into account the age and abilities of the child (THOMPSON, 1969), some examples are: pushing the cotton in the pots; searching for work-tools; carrying out small chores. However, it was not uncommon for four- or five-year-olds to work as chimney sweepers, hired because they were thin enough to climb into narrow tunnels. The use of children as chimney sweepers is witnessed by English literature. Think for example of Dickens' works, especially Oliver Twist. Children at an early age often developed cancer due to repeated exposure to by-products of coal burning (MACKENZIE, 2008). Sometimes, to speed children up, a fire would purposely be lit so the children would climb the chimney faster. The living conditions in London in 1800 were deplorable: often children were also involved in mining, and subject to very dangerous sanitary conditions. The lack of air and sunlight led children to develop numerous lung diseases. These examples make it clear that children were part of the workforce since their early years (PANCERA, 2001) and that young people, even if very young, were considered skilled enough to contribute to family life and business.

Around the age of six/seven, children were sent to serve in shops in order to gain experience. The terms of employment were agreed upon by parents and the employer. The young apprentices were totally obedient and loyal to the master. In exchange he would treat them as part of the household, educating and raising them, and treating them coherently with their age. It remains to be understood: what is meant by "coherently with their age'? Was the treatment only commensurate to the physical strength of the child or were there other specific characteristics of childhood that were taken into account? As Carlo Pancera (2001) states, these new conditions were experienced by the child as an entry into society, as a form of initiation into adult life.

The compagnos played a fundamental role in transmitting knowledge and skills necessary to carry out the work. A compagno was generally a child with several years of experience who had the task of showing the newcomers how to perform the required tasks. In pedagogical terms, we see how society invested in peer education. Certainly, the conditions of the time determined this investment but, also makes us, 21st-century adults and educators, reflect on what it means to speak of 'competency' in relation to childhood. Investing in child labour was a family strategy (DAVIS, 1977) aimed at improving the status of the entire family group. Tendentially the first-born son had the task of pater 
familias $^{3}$, of successor, the one who was to carry on the fate of the house. As Kagan mentions, children were given the opportunity to be appreciated and valued through the results of their work (Kagan, 1976). Values such as succession, being part of the concrete livelihood of the family life, the importance of a "good name" and even the concept of good reputation were all key dimensions in models of good child behaviour. Although these models are far away from the today's idea of childhood and protection and even if child labour is legally prosecutable, it should be noted that the working environment, the rhythms and training objectives of the craft workshops in the pre-industrial era were less obsessive and alienating than those produced by the factory system, developed in the 1800's when children were still being employed. Furthermore, children's competency was not only recognized within the domestic walls but also in the public sphere as workers. Even though, perhaps, children did not exist as a category as Ariès argues, they certainly took part in public life where they played crucial roles for the survival of their families and the economy in general.

The interest in childhood as a social group (Di BELLO, 2001) and in children as subjects worthy of attention by the adult world has taken different connotations along the historical periods. It is possible to observe a strong attention towards marginalized childhood. The first measures in legislation concerning child protection were given by Thomas Spence, who in 1797 published The Rights of Infantes. Active in radical politics, he became a schoolteacher in the course of which he first presented his land plan in 1775.

During the second half of the 19th century, the conception of the State as "protector" of childhood developed (Di BELLO, 2001). This also contributed to redefine the "guidelines" of an appropriate parent-child relationship, limiting the parental power of the head of the household. Patria Potestà (father's power) is one of the pillars of the Roman tradition, which enshrined the perpetual right to decide over the life and death of one's own children (BORRUSO, 2013). This principle underpins the concept of corrective power, the ius corrigendi $i^{4}$, which historically was exercised by parents towards their children in the form of corporal punishment and violence.

An important legislative breakthrough in favour of the protection of children can be retrieved in Italy by the 1866 legal provisions concerning child labour. The law prohibited children under nine years of age to work in mines and industries. Then, education gradually started leaving the workplace but still maintained a moralizing goal through educational and welfare interventions aimed at the formation of the future honest, working citizen; and poor children were especially targeted in order to repress all forms of deviance. Education and protection were seen as important to form the future adult, the future citizen that the child would become. So, attention was not yet given to childhood as a specific category with its own intrinsic value.

Between 1874 and 1875, the New York Society for The Prevention of Cruelty to Children (NYSPCC) was founded. Established in 1875, it was the first child protection agency in the world. Throughout its distinguished history, the NYSPCC has sought

3- Latin expression that indicates the male head of a family or household.

4- Latin expression to indicate the right to discipline. 
to develop and implement innovative mental health, as well as legal and educational programs to protect children from harm and make sure they had a healthy development.

The $20^{\text {th }}$ century was marked by important legislative developments in the field of child protection which conceived children as bearers of rights. An example is the foundation, in 1919, of Save the Children by Eglantyne Jebb. She had a vision: to achieve and protect the rights of children worldwide. She was driven by the belief that all children "whoever they are, wherever they are" have the right to a healthy, happy, fulfilling life. A similar fact took place in 1923 with the Declaration on the rights of the child, which was the first and the most important expression of international law specifically aimed at children. But there were also changes in the living conditions of children, such as the progressive development of the nuclear family and the spread of compulsory schooling. Unfortunately, forms of corrective power and violence against children would also be present in the schools.

From a different perspective, other historians (POLLOCK, 1983; HANAWALT, 1993) disagree with a drastically negative view of the conditions of childhood, allegedly ignored and abandoned, invisible to society; instead, they show how play and participation in public rituals and celebrations were part of the children's life as well. Children were social actors and left traces of their existences. For example, in Italy in the 1930s, a social occasion that included the participation of the entire family, was threshing. The threshing was an important moment in which farmers from other areas joined together for a collective gathering of food, a sort of festival to celebrate abundance and the defeat of poverty and hunger (ULIVIERI, 2001). Although still very young, each child had their own role in the festival. Another similar opportunity of participation in the communal life was the harvest when children had the task of collecting the grapes dropped by the harvesters or, in the case of older children, take care of the new-borns and the youngest. These were moments of transition in which children participated in the community by observing and internalizing adult norms and behaviour, some sort of rite of passage. These were also moments when adults recognized and valued the role of the youngest members of their communities.

The historical evolution so far briefly exposed, supported by theoretical speculation - think for example of the prominence proposed by J. J. Rousseau (BORRUSO, 2013) which led to the construction and sedimentation of what Philippe Ariès first defined as "childhood feeling" (ARIĖS, 1962). In his main work, Emile, Rousseau warns against "the desire to make men of them [children] before their time" (ROUSSEAU, [1762] 2002, p. 108). Rousseau's words highlight his primary concern, that is, to allow children to be children. As Scholz (SHOLZ, 2010) reminds us, childhood (for Emile), unlike adulthood, should not suffer under the constraints of property. Freedom means deciding for oneself what is one's own good and not being ruled by external constraints.

Although the 'discovery' of childhood was anything but linear, rather full of contradictions (CAMBI, 1988), it is not possible to mention a single idea of childhood (considering, for example, the substantial differences arising from class or gender). Ariès has become a point of reference for studies on child condition (FRUGIUELE, 1990). Ariès contributed to highlight how the representation of a specific phase of life has a cultural 
connotation and this led him to see childhood not as a pre-constituted and unilateral stage, but as a complex condition resulting from "nature and culture" (CENSI, 1994).

The paragraphs above sought to briefly reconstruct the evolution of the concept of childhood along history and through a legal reconstruction of the rules specifically designed to protect children. As can be seen, low protection of children's rights corresponded to high levels of socio-economic participation (and exploitation) and vice-versa (JANS, 2004).

Today there are many organizations, public and private, committed to child protection $^{5}$, most of them are governmentally sponsored, while others are nongovernmental (GARDNER, 2016). As it will be discussed in the following paragraphs, specifically dedicated to the theme of participation and democracy, today's approach to child protection is not to be understood as a mere welfare application "on" children. Participation rights are enshrined by the UNCRC (art. 12, 13,14, 15, 16, 17, 30, 31), by General Comment No. 12 of the Committee on the Rights of the Child and by the Third optional protocol to the Convention ${ }^{6}$. These documents affirm the status of the child as a holder of rights and as a human being with dignity and evolving capacities (SMITH, 2014). Still, the balance between protection rights and participation rights, both theoretically and empirically, remains one of the most debated aspects within the sphere of children's rights (PERCY-SMITH; THOMAS, 2010).

\section{The UNCRC and child participation}

The process of liberation, protection and emancipation of childhood (LINDSAY, 1992), described in the previous paragraphs, brought to the adoption of the United Nations Convention on the Rights of the Child (1989). First of all, who is a child? Article 1 of the UNCRC states that: "For the purposes of the present Convention, a child means every human being below the age of eighteen years, unless under the law applicable to the child, majority is attained earlier". Age is, therefore, the discriminant factor that establishes which human subjects are children and which are not. Before 1989, the concept of children's rights had often been framed in terms of beliefs about their nature and needs, and about adults' responsibilities towards them. Now the Convention recognizes childhood as an individual with juridical value, so a bearer of rights. This means that children are not only entitled to special protection (art.5, 3.2, 6, 19, 32, 33, 34, 36) but to a certain amount of participation rights, because they are considered active agents of their lives (art. 12, 13, $14,15,16,17,30,31)$.

\footnotetext{
5- UNICEF has made a list, which can be found on its website (https://www.unicef.org/protection/57929_57977.html) dealing with current child protection issues such as: Armed violence reduction; birth registration; child labour; child marriage; children affected by armed conflict; child trafficking; children without parental care; children with disabilities; female genital mutilation/cutting; justice for children; landmines and explosive weapons; monitoring and reporting mechanism (MRM) on grave violation of children's rights in situation of armed conflict; mental health and psychosocial support; sexual violence against children.

6- «The third Optional Protocol to the Convention on the Rights of the Child presents complaint procedures and expressly enshrines the right of minors to report violations of their rights. The Protocol went through a tenth ratification in April, 2014. According to the Protocol, any individual child or group of children may submit complaints relating to specific violations of their rights as enshrined in the Convention, the Optional Protocol on children in armed conflicts and the Optional Protocol on sale of children, pornography representing minors and child prostitution».
} 
The following paragraphs focus on the concept of child participation as it is one of the key aspects that substantiates the connection between children's rights, education and democracy.

The UNCRC, which encompasses an extensive range of rights -civic, political, social, cultural and economic- is the foundation on which much child participation theory, research and practice is now built. Children's participation has been one of the most debated aspects of the Convention since it was adopted and it still lacks clarity about its meaning (PERCY-SMITH; THOMAS, 2010).

First of all, how does the Convention define child participation? The UNCRC does not cite participation as a right, so the debate around the concept, still in progress, was particularly sharp till 2009 when General Comment No.12 of the Committee on the Rights of the Child linked UNCRC's Article 12 to the concept of participation, where the second paragraph reads as follows:

1. States Parties shall assure to the child who is capable of forming his or her own views the right to express those views freely in all matters affecting the child, the views of the child being given due weight in accordance with the age and maturity of the child.

2. For this purpose, the child shall in particular be provided the opportunity to be heard in any judicial and administrative proceedings affecting the child, either directly, or through a representative or an appropriate body, in a manner consistent with the procedural rules of national law.

The Committee adds a new ' $\mathrm{P}$ ' to provision and protection, that is, participation, another key principle. Children are recognized, as previously mentioned, as subjects of rights and now as agentic beings. Specifically, Article 12 depicts them as political agents. Here is where we find a crucial link between children's rights and democracy.

\section{Child participation and democracy}

Democracies are forms of government that represent the demos, the people in the exercise of power. Despite the fact that the exercise of power, in the last two centuries, has gradually been extended to minorities and previously marginalized groups - for instance, women and the poor -, it is not usually extended to children. Children rarely enjoy significative democratic rights to influence policies, to pass laws, or elect representatives. This is because the socio-cultural image of childhood sees them as incomplete, irrational, or too dependent beings (MACINAI, 2013) thus unable to exercise the levers of power for themselves, not to mention the ambiguities contained in the UNCRC itself. Article 12 applies to every child capable of forming her/his own views. The term 'capable' leads to questions concerning who acknowledges capability and on what basis: usually those with the power to do so: the adults (WHITE, 1996). Children have the right to express their views freely in all matters affecting them. But which matters affect a child? It has been argued, for instance, private matters only (CANTWEEL, 2011), excluding whatever concerns the public good. Children's views should be given due 
weight in accordance with their age and maturity, but, again, who establishes how much a child's view should weigh?

The role, form, weight of children's participation challenge the meanings of democracy and citizenship and demands a shift from democracy thought exclusively as a governmental form and a political system to democracy as a form of living together in a community, characterized by how decisions are made, conflicts are handled, in order to create a space in which different people are able to freely choose amongst different solutions. To this end, Roger Hart says that "a nation is democratic to the extent that its citizens are involved, particularly at the community level” (HART, 1992, p. 4). Moreover, he adds that "it might be argued that 'participation' in society begins at the moment a child enters the world and discovers the extent to which she or he is able to influence events through claims or movements" (HART, 1992, p. 4). So, in this perspective, participation is the means by which a democracy is built and a standard by which it can be measured (HART, 1992, p. 5). This demands active, competent, critical and responsible citizens if they are to exercise shared responsibilities amidst social, economic and institutional diversity. At the same time, in contemporary society, trust in democracy as a form of government is decreasing, politicians are depicted as being untrustworthy, and doubt is cast on their ability to mediate social decisions, decreasing political participation across all cohorts. In this regard, research has been conducted on youth councils, an adult attempt to promote civic engagement among the young. Two qualitative studies on politically active young people in North and Latin America show how some teenagers perceive the councils not only as elitist and non-representative but also as forms of social control (TAFT; GORDON, 2013). This may have two outcomes: the first, not feeling in control of one's own life and questioning one's own role as citizen or the necessity of engaging in politics (HART; HENN, 2017); the second, engaging in different forms of activism led by children or youths, for instance. In the United Kingdom, the same weaknesses emerge: the young delegates mention how often their voices are overshadowed (MATTHEWS, 2001), how the councils risk being a 'white elephant' (MATTHEW; LIMB, 2003). This is only apparently in contradiction with those movements demanding to lower the voting age: the young, in fact, are putting forth a theory of democracy that emphasizes authority and impact, not just voice. To this end, one may consider, for example, how the "Children (Equal Protection from Assault) (Scotland) Act 2019", the so called 'no smacking ban', was created. On the $11^{\text {th }}$ of May, 2017, a draft bill was published. It was accompanied by a consultation running from the $12^{\text {th }}$ of May through the $4^{\text {th }}$ of August, 2017. Besides posting the consultation document on the Scottish Parliament's website, it was sent to many organizations:

- All 32 local authorities in Scotland;

- 12 charities;

- 7 equality organizations;

- 12 police, legal, or human rights bodies;

- 20 medical and care professional organizations. 
Of these organisations, the Youth Parliament presented the results of a mass consultation conducted on their manifesto "In our Lead the Way (2016-2021)" where $82 \%$ of respondents aged 12-25 supported the statement: "All physical assaults against children should be illegal".

Also, the 'no smacking ban' proposal was discussed with $6^{\text {th }}$ graders in Edinburgh, where six out of eight respondents overwhelmingly supported the proposal and created a list of motivations for doing so (FINNIE, 2017).

This case presents food for thought. The UNCRC in fact proved to be a strong instrument expressing all its potential within the Scottish democracy and, in turn, contributed to broaden the boundaries related to what the democratic way of living means. Article 19 of the UNCRC protects children from all forms of violence and article 12 recognizes children's right to participate in decision-making. Protection was gained through children's participation, which is not always the case, contributing to a (subversive) cultural shift. Because Scottish children are now recognized with full human dignity, they are entitled to full protection and recognized as capable political agents. This example shows how much politics and education are intertwined, a connection that will be discussed in the next section.

\section{Child participation, education and democracy}

At the beginning of the $20^{\text {th }}$ century, John Dewey (2008 [1916]) promoted the idea that education is fundamental for building a democratic society. He argued that the quality of democracy depends on the quality of education and the concept of education itself acquires value only if in favour of the development of a democratic society. Democracy is, in fact, not only about extending voting rights, a major issue in 1916, but also about equipping citizens with the ability to responsibly make informed decisions on behalf of the public good. John Dewey believed that democracy is not only a political system but an ethical ideal relying on active informed participation of citizens. By drawing on these reflections, Peter Moss (2007, p. 3) argues that there are three main reasons for which democratic practice in education is crucial, starting right from the early years:

- First, it is a right of citizenship, a way through which children and adults can participate in the decision-making.

- Second, it provides a means for resisting oppression and injustice and unaccountable exercise of power.

- Third, it encourages differences to flourish, promoting new ways of thinking and acting.

This means that democracy creates space for new knowledge and practices to be created and influences the ways they are distributed. Democratic participation in fact can contribute in building a community of solidarity based on shared values and on reciprocal esteem (THOMAS, 2012), a community in which opportunities and resources are available for every individual to realise her/his capacities and powers and contribute to the public 
good. This way of thinking completes the contemporary views of education that see it only as a mere technical practice, a place in which technologies can be applied to produce certain outcomes and educational services are seen as competing businesses in a private market. Technologies, scientific progress and business are surely important components when thinking of education but are just some of the aspects that need to be considered, whereas they tend to be dominant.

With a democratic way of living - which places itself through the forms of democracy guaranteed and practiced by the State -, the sense of citizenship and participation needs to be learnt. One can be born with certain rights, but one is then to become an active citizen. The educational dimension emerges when citizenship moves from the entitled of rights (legal dimension) to the concrete possibility of exercising them (political dimension) (TAROZZI, 2015, p. 72). Citizenship is the space where the educational dimension and the political dimension get together because active citizenship requires an explicit and aware educational process (BERTOLINI, 2003, p. 148), but it is also the assumption at the base of education. It is by learning to question, to express views and have them taken seriously that children will acquire the necessary competences to develop their thinking and to exercise judgement in the issues they are confronted with (WHITE, 1996) rather than suddenly, at the age of eighteen, be expected to be active voting citizens. Since the aim is to live democracy, children need to be given chances of experimenting the meanings of active citizenship; the possibility to exercise a potentially emancipated and subversive participation, where conflict with adults, who are the ones who establish the terms of participation, can be challenged (WHITE, 1996). School plays a crucial role in engaging and challenging students, by relating learning to experience and by listening to the voice of the learners. School is a space and time where and when children's political agency (KALLIO; HÄKLI, 2013) can be fostered, where the political meaning of education (BERTOLINI, 2003) can emerge. Thanks to early opportunities of democratic participation, children can develop a sense of collective ownership and responsibility, learn to solve problems collaboratively and, moreover, develop belief in themselves as actors who have the power to impact the conditions that shape their lives.

This way of thinking underpins the ontological assumption according to which every human being is constituted by a 'being-with', where singularity is realized within plurality. But when thinking about children this 'being with' or the interpretation given to this term often obstructs their real possibilities of exercising their rights, especially their participatory rights. An example is participation within the Child Protection System (CPS). In the CPS, children are viewed as in need of special care and protection and, for this reason, it is all too easy to exclude them from the decision making, turning the tension between participation rights and protection rights particularly visible (HEIMER; NÄSMAN; PALME, 2018; VIS; HOLTAN; THOMAS, 2012).

\section{The 2030 democracy and childhood}

The United Nations 2030 Agenda for Sustainable Development (UNITED NATIONS GENERAL ASSEMBLY, 2015) constitutes the latest policy document that contains 
dispositions concerning children and their rights. It is informed by the UNCRC but takes a step forward by defining specific goals that must be achieved by 2030 in order to develop society to make it just, equitable and peaceful; one could say as a truly democratic society in which no one is left behind. To this end, goal 16 "Promote peace, justice and strengthen institutions" is a concrete opportunity for the UN Member States, academia and civil society to discuss the meanings of democracy.

There are many synergies between the SDGs and children's rights: they both envisage a transformed world, recognize that rights and development are interdependent and promote international cooperation (JAMIENSON; BERRY LIZETTE; LAKE, 2017). Whereas the UNCRC focuses on children, providing a code of rights and guidelines for future development specifically for children and their needs, the 2030 Agenda has a broader view and targets human beings, where children are just one element of the 2030 Agenda.

Children in the 2030 Agenda are considered a vulnerable group among many others (Declaration, para. 23. SDGs 4.5, 5.2, 11.2, 11.7). It can be said that, if on one hand there is little risk of losing sight of children in the 2030 Agenda, on the other hand, labelling children as vulnerable has many and potentially dangerous consequences for childhood and society as a whole. It is important to think of what vulnerability means. Vulnerability seems to be considered as 'structurally related' to children, as if a child is itself a vulnerable subject. From a pedagogical perspective, the crucial point is to understand under which conditions children are vulnerable and who or what is the potential offender. The position that we take here is that vulnerability is different from dependence when referred to children (BIFFI, 2020). Vulnerability in fact is a condition. Specifically, a vulnerable condition originates when, in spite of a critical event, activating personal and public resources does not generate a renewed existential balance. So, vulnerability is not a structural component of childhood but a condition. Moreover, pedagogically speaking (BERTOLINI, 1958; MORTARI, 2016), human beings are dependent, or better, interdependent. Not only children depend on adults, but dependence is part of the experience of being human. The phenomenological approach to pedagogy particularly stresses this aspect, highlighting how 'being' means being-in-the-world (Dasein), specifically being with (Mitsein) Others (das Man) (HEIDEGGER,1962).

This means that, from a phenomenological perspective to education and from a rights-based view, children are entitled to special protection and to specific SDGs, not because of their vulnerability - which leads not only to over-protectionism but to looking at the child as an infant, therefore lacking logos (MACINAI, 2013). This is such an extremely violent view because it deprives children from their identity, and also because specific needs require specific rights and strategies in order to promote human flourishing.

Furthermore, the UNCRC, as a result of its participatory rights, recognizes children as active agents of their own protection, recognizes them as intentional beings, as experts of their own lives who can exercise their own rights even under conditions of vulnerability. Therefore, children should also have the right to participate when involved with the child protection system.

The UNCRC creates the cornerstone not only to consider children holders of rights but also recognizes children in flesh and bones as political agents, as members of society who, 
according to a democratic way of living, can learn to take part in making decisions which concern the community. Today, children can benefit from these institutional recognitions and are trying to make their voices heard in matters that concern them, or better, in matters that affect society as a whole: for instance, the spontaneous movement of the Fridays For Future, that is asking to enhance the care of the Earth; another example is the more structured experience of the Eurochild Children's Council, formed by representatives from twelve European States and is trying to make the continent a better place for children; there is also the Scottish Children's and Youth's Parliament. These examples clearly show how the UNCRC has laid ground for children to experience democracy as a way of living with others, with the older generations from whom one learns and with peers with whom one builds a shared view of life. Adults, especially those working in the pedagogical field, need to contribute to create experiences in which children can exercise their potentially subversive power - as, for instance, how the Scottish 'no smacking ban' was created and developed belief in themselves as actors who have the capability to impact the conditions that shape their lives, in accordance with the UN 2030 Agenda and, of course, with the United Nations Convention on the Rights of the Child. But childhood is still an atrisk category. The current Covid-19 pandemic provides a powerful lens to observe the conditions of childhood: one of the most fragile categories and at the same time one of the most neglected and left behind, even in the so called wealthy countries (UNICEF, 2020).

In conclusion, the UNCRC assumed a fundamental role in protecting and supporting children and it encouraged societies in re-defining their perception of childhood in general. On the other hand, it risks becoming an obstacle for the future development of the culture of childhood if it is considered as the final destination of the process. It is extremely important to proceed with building the conditions of an updated role of childhood in our societies which is able to consider children as actors in our present, where they are no longer considered as 'vulnerable' by definition. In a certain way, a future where the UNCRC will not be necessary.

\section{References}

ALESSANDRINI, Giuditta. La "pedagogia" di Martha Nussbaum: approccio alle capacità e sfide educative. Milano: FrancoAngeli, 2014.

ARIES, Philippe. L'enfant et la vie familiale sous l'Ancien Régime. v. 286. Random House, 1962.

BECCHI, Egle. I bambini nella storia. Roma-Bari: Laterza, 1994.

BERTOLINI, Piero. Fenomenologia e pedagogia. Bologna: Malipiero, 1958.

BERTOLINI, Piero. Educazione e politica. Milano: Raffaello Cortina, 2003.

BIFFI, Elisabetta. Cosa può fare ed essere un bambino oggi? Riflessioni pedagogiche sul contributo dell'infanzia nella società contemporanea. Milano, Pedagogia Oggi, v. 16, n. 2, p. 205-225, 2018. 
BIFFI, Elisabetta. II rovescio della trama educativa. Milano: Franco Angeli, 2020.

BORRUSO, Francesca. Ti do io una buona lezione che ricorderai a lungo. Metodi educativi e violenza sull'infanzia nella storia dell'educazione fra Sette e Novecento. Milano, Pedagogia Oggi, v. 11, n. 2, p. 8099, 2013.

CANTWEEL, Nigel. (2011). Are children's rights still human? In: INVERNIZZI, Antonella; WILLIAMS, Jane (ed.). The human rights of children: from visions to implementation. Fernaham: Ashgate, 2011. p. 37-59.

CENSI, Antonietta. La costruzione sociale dell'infanzia. v. 49. Milano: FrancoAngeli, 1994.

DAVIS, Natalie Zemon. Ghosts, kin, and progeny: Some features of family life in early modern France. Daedalus, p. 87-114, 1977.

DEWEY, John. Democracy and education. [S. I.: s. n.]: 2008. Retrieved from: http://www.gutenberg.org/ ebooks/852

FINNIE, John. Proposed children (Equal protection from assault) (Scotland) Bill. [S. I.: s. n.]: 2017. Retrieved from: http://www.scottish.parliament.uk/parliamentarybusiness/Bills/25690.aspx.

FLANDRIN, Jean-Louis. Familles: parenté, maison et sexualité dans I'ancienne société. Paris: Le Seuil, 2014.

FRUGIUELE, Gabriella M. Dalla scoperta alla scomparsa dell'infanzia. Studi di Sociologia, v. 28, n. 3, p. 387-398, 1990.

GARDNER, Sid. The future of the fifth child: an overview of global child protection programs and policy. [S. I.]: Iunivers, 2016.

GIALLONGO, Angela. "L'infanzia Iontana: temi iconografici dal Medioevo". In: COVATO, Camela; ULIVIERI, Simonetta (ed.). Itinerari nella storia dell'infanzia: bambine e bambini, modelli pedagogici e stili educativi. Milano: Unicopli, 2001. p. 45-77.

HANAWALT, Barbara A. Growing up in medieval London: the experience of childhood in history. Oxford: Oxford University Press, 1995.

HART, Roger. Children's participation: from tokenism to citizenship. Innocenti Essays, 1992. Retrieved from: https://www.unicef-irc.org/publications/pdf/childrens_participation.pdf.

HEIDEGGER, Martin. Being and time. Translated by John Macquarrie \& Edward Robinson. Oxford; Cambridge: Blackwell, 1962.

HEIMER, Maria; NÄSMAN, Elisabet; PALME, Joakim. Vulnerable children's rights to participation, protection, and provision: the process of defining the problem in Swedish child and family welfare. Child and Family Social Work, v. 23, n. 2, 2018. https://doi.org/10.1111/cfs.12424, p. 316-323 
JAMIENSON, LuCy; BERRY LIZETTE; Lake. Setting an ambitious agenda for children: the sustainable development goals. [S. I.: s. n.], 2017. Retrieved from: http://www.ci.uct.ac.za/sites/default/files/image_ tool/images/367/Child_Gauge/South_African_Child_Gauge_2017/Child_Gauge_2017_lowres.pdf

JANS, Marc. Children as citizens: towards a contemporary notion of child participation. Childhood, v. 11, n. 1, p. 27-44, 2004.

KAGAN, Jerome. The child in the family. Daedalus, v. 106, n. 2, p. 33-56, 1977.

KALLIO, Kirsi Paulina; HÄKLI, Jouni. Children and young people's politics in everyday life. Space and Polity, v. 17, n. 1, p. 1-16, 2013.

LINDSAY, M. Highlight: an introduction to children's rights. London: National Children's Bureau, 1992.

MACINAI, Emiliano. Pedagogia e diritti dei bambini: uno sguardo storico. Roma: Carocci, 2013.

MACKENZIE, Ann Halley; DICKENS, Charles. An analysis of environmental issues in 19th century England using the writings of Charles Dickens. The American Biology Teacher, v. 70, n. 4, p. 202-204, 2008.

MATTHEWS, Hugh. Citizenship, youth councils and young people's participation. Journal of Youth Studies, v. 4, n. 3, p. 299-318, 2001. https://doi.org/10.1080/13676260120075464

MATTHEWS, Hugh; LIMB, Melanie. Another white elephant? Youth councils as democratic structures. Space and Polity, v. 7, n. 2, p. 173-192, 2003. https://doi.org/10.1080/1356257032000133928

MORTARI, Luigina. Cultura della ricerca e pedagogia: prospettive epistemologiche. Roma: Carocci, 2016.

MOSS, Peter. Bringing politics into the nursery: early childhood education as a democratic practice. European Early Childhood Education Research Journal, v. 15, n. 1, p. 5-20, 2007. https://doi. org/10.1080/13502930601046620

PANCERA, Carlo. La socializzazione dell'infanzia lavoratricenell'età preindustriale. In: COVATO, Carmela; ULIVIERI, Simonetta (ed.). Itinerari nella storia dell'infanzia: bambine e bambini, modelli pedagogici e stili educativi. Milano: Unicopli, 2001, p. 125-146.

PERCY-SMITH, Barry; THOMAS, Nigel. A handbook of children's participation: perspectives from theory and practice. UK: Routledge, 2010.

ROTTERDAM, Erasmo. Sulle buone maniere dei bambini. Roma. Armando, 2000.

ROUSSEAU, Jean-Jacques. Emilio o dell'educazione (Edizione integrale. ed., Classici della pedagogia 7). Firenze: La nuova Italia, 2002. Original work published 1762.

SCHOLZ, Sally J. That all children should be free: Beauvoir, Rousseau, and childhood. Hypatia, v. 25, n. 2, p. 394-411, 2010. 
SEVESO, Gabriella. Come ombre leggere: gesti, spazi, silenzi nella storia dell'educazione delle bambine. Milano: Unicopli, 2000.

SMITH, Rhona. The Third Optional Protocol to the UN Convention on the Rights of the Child: challenges arising transforming the rhetoric into reality. In: FREEMAN, Michael (ed.). The future of children's rights. Boston: Brill Nijhoff, 2014. p. 178-195.

SPENCE, Thomas. The rights of infants (1797). In: CUNLIFFE, John; ERREYGERS, Guido (ed.). The origins of universal grants. London: Palgrave Macmillan, 1982. p. 81-91.

TAFT, Jessica K.; GORDON, Hava R. Youth activists, youth councils, and constrained democracy. Education, Citizenship and Social Justice, v. 8, n. 1, p. 87-100, 2013.

TAROZZI, Massimiliano. Dall'intercultura alla giustizia sociale: per un progetto pedagogico e politico di cittadinanza globale. Milano: Franco Angeli, 2015.

THOMAS, Nigel. Love, rights and solidarity: studying children's participation using Honneth's theory of recognition. Childhood, v. 19, n. 4, p. 453-466, 2012.

THOMPSON, Edward P. The making of the English working class. New York: Open Road Media, 2016.

UNICEF. Worlds of influence: understanding what shapes child well-being in rich countries. [S. I.]: Unicef, 2020. Retrieved from: https://www.unicef-irc.org/child-well-being-report-card-16.

UNITED NATIONS GENERAL ASSEMBLY. Transforming our world: the 2030 Agenda for Sustainable Development. In: DAWS, Sam; WEISs, Thomas G. (ed.). The Oxford handbook on the United Nations. Oxford: [s. n.], 2015. Disponível em: https://sustainabledevelopment.un.org/post2015/transformingourworld. Acessado em: 21 out. 2020.

VIS, Svein Arild; HOLTAN, Amy; THOMAS, Nigel. Obstacles for child participation in care and protection cases-why Norwegian social workers find it difficult. Child Abuse Review, v. 21, n. 1, p. 7-23, 2012.

WHITE, Sarah C. Depoliticising development: The uses and abuses of participation. Development in Practice, v. 6, n. 1, p. 6-15, 1996. https://doi.org/10.1080/0961452961000157564

Received on June 02nd, 2020

Reviewed on July $22^{\text {th }}, 2020$ Approved on September 14 1 th 2020

Chiara Carla Montà is a PhD candidate in "Education in the Contemporary Society" at the "Riccardo Massa" Department of Human Sciences for Education, University of Milano-Bicocca (Italy). Her research interests concern: children's rights, with a specific focus on participation; violence against children; educational policy. 
Lucia Carriera is a Research assistant at the "Riccardo Massa" Department of Human Sciences for Education, University of Milano-Bicocca (Italy). Her main research interests are photography in educational research, $A B R$ methods, narrative inquiry, the educational dimension of space and pedagogical documentation.

Elisabetta Biffi is an Associate Professor in Pedagogy at the "Riccardo Massa" Department of Human Sciences for Education, University of Milano-Bicocca (Italy). She teaches "Pedagogical counselling" as part of the Master's Degree Course in Pedagogical Sciences and "Educational Intervention" as part of the Bachelor's Degree Course in Education. 